Canadian University Music Review

Revue de musique des universités canadiennes

\title{
Topos, Text, and the Parody Problem in Bach's Mass in B minor, BWV 232
}

\section{Lisa Szeker-Madden}

\section{Numéro 15, 1995}

URI : https://id.erudit.org/iderudit/1014395ar

DOI : https://doi.org/10.7202/1014395ar

Aller au sommaire du numéro

\section{Éditeur(s)}

Canadian University Music Society / Société de musique des universités canadiennes

\section{ISSN}

0710-0353 (imprimé)

2291-2436 (numérique)

Découvrir la revue

Citer cet article

Szeker-Madden, L. (1995). Topos, Text, and the Parody Problem in Bach's Mass in B minor, BWV 232. Canadian University Music Review / Revue de musique des universités canadiennes, (15), 108-125. https://doi.org/10.7202/1014395ar

\section{Résumé de l'article}

Even though parody and borrowing have long been recognized as legitimate features of Bach's compositional practices, the criteria by which the composer selected appropriate material to parody remains problematic. Christoph Wolff and Güther Stiller, for example, suggest that musical elements, such as the quality of the original or its potential for further embellishment, represent possible criteria. On the other hand, textual elements such as analogous subjects, "affects," and metrical patterns between old and new texts also many have factored into Bach's criteria. In an effort to redress the imposition of these twentieth-century solutions to what is in effect an eighteenth-century phenomenon, this study undertakes a cultural/contextual examination of the Crucifixus movement from the Mass in B minor and its model, the opening chorus of Cantata 12. Indeed, a logical analysis of both texts reveals that an equivalence of topoi, or topics, represents an important criterion in the selection of an appropriate model from which to borrow. Moreover, a musical-rhetorical analysis confirms that Bach's borrowings from the opening chorus of Cantata 12 are actually musical-rhetorical figures. His application of the parody procedure thus represents the re-use of specific musical-rhetorical gestures which are suitable for the embellishment of a particular topos.
All Rights Reserved (C Canadian University Music Society / Société de musique des universités canadiennes, 1995
Ce document est protégé par la loi sur le droit d'auteur. L'utilisation des services d'Érudit (y compris la reproduction) est assujettie à sa politique d'utilisation que vous pouvez consulter en ligne.

https://apropos.erudit.org/fr/usagers/politique-dutilisation/ 


\title{
TOPOS, TEXT, AND THE PARODY PROBLEM IN BACH'S MASS IN B MINOR, BWV 232*
}

\author{
Lisa Szeker-Madden
}

Although Johann Sebastian Bach's use of parody and borrowing techniques is well-documented, ${ }^{1}$ determination of the specific criteria by which he chose appropriate sources remains problematic. Indeed, recent scholarship in this area presents two disparate hypotheses. Christoph Wolff, Günther Stiller, Robin Leaver and Gesa Kordes suggest that Bach's primary concern in the selection of a model involved both the overall musical quality of the original work as well as its potential for further melodic embellishment. ${ }^{2}$ On the other hand, Wolff and Leaver recognise obvious similarities between the texts of the models and the texts of their respective parodies, such as analogous subject matter or "affects,"

* The original of this paper was submitted to Dr. Erich Schwandt as part of a graduate seminar under his direction at the University of Victoria. I would like to thank Dr. Schwandt for his critical reading of the various drafts of this essay and for his many helpful suggestions. A version of this paper was presented at the 1994 meeting of the Canadian University Music Society in Calgary, Alberta, where it was awarded the George Proctor Prize.

1 Hans-Joachim Schulze, in "The Parody Process in Bach's Music: An Old Problem Reconsidered," Bach 20 (1989): 7-21, summarises the conclusions of leading scholars in this area such as Wilhelm Rust, Friedrich Smend, Ludwig Finscher, Werner Neumann, and Günther Stiller. See also Arnold Schering, "Über Bachs Parodieverfahren," Bach-Jahrbuch 18 (1921): 49; Paul Brainard, "Bach's Parody Procedure and the St. Matthew Passion," The Journal of the American Musicological Society 22 (1969): 241-49; Robert L. Marshall, The Music of Johann Sebastian Bach: The Sources, the Style, the Significance (New York: Schirmer, 1989), 33, 178-80; Christoph Wolff, Bach: Essays on His Life and Music (London: Cambridge, 1991), 141, 147. For contemporary endorsement of borrowing and parody see Johann David Heinichen, Der Generalbass in der Komposition (Dresden, 1728), 31, and Johann Mattheson, Critica Musica, (Dresden, 1722), 71, both of whom state that the re-use of previously composed is acceptable, so long as the borrowing represents an improvement over the model. For more on the difference between parody and borrowing, see Martin Lutz, "Parodie und Entlehnung bei Händel" in Georg Friederich Händel: Ausstelhung aus Anlass der Händel-Festspiele des Badischen Staastheaters Karlsruhe, ed. Klaus Häfner and Kurt Pietschamann (Karlsruhe: Badische, 1985), 81-94.

2 Wolff, Bach: Essays on His Life and Music, 334; Wolff, "Bach the Cantor, the Capellmeister, and the Musical Scholar: Aspects of the B-minor Mass," Bach 20 (1989): 61,; Günther Stiller, Johann Sebastian Bach and Liturgical Life in Leipzig (St. Louis: Concordia Publishing, 1984), 288; Robin A. Leaver, "Parody and Theological Consistency: Notes on Bach's A-Major Mass," Bach 21 (1990): 30; Gesa Kordes, "Self Parody and the 'Hunting Cantata' BWV 208: An Aspect of Bach's Compositional Process," Bach 22 (1991): 38. 
and thus confirm that a congruence between old and new texts represents an important aspect of Bach's criteria. ${ }^{3}$ Furthermore, Hans-Joachim Schulze reveals an additional correspondence between model and parody texts through his observation that they often share identical metrical patterns and prosody. ${ }^{4}$ These suggestions, however, fail to account for the influence of verbal or musical rhetoric in Bach's selection of sources and consequently are removed from the culture and context of the eighteenth century. ${ }^{5}$ The following thus presents a contextual examination of Bach's application of the parody procedure through logical and rhetorical analyses of the opening chorus from Cantata 12, "Weinen, Klagen, Sorgen, Zagen," and its parody, the Crucifixus of the Mass in B minor, BWV 232. ${ }^{6}$ As a result, this study demonstrates that Bach's selection of suitable sources from which to borrow involved more than a consideration of elements such as musical quality or superficial affinities between old and new texts. In fact, the deepest levels of the verbal and musical rhetorical structure significantly influenced Bach's choice of appropriate material to parody.

The contextual examination of an eighteenth-century vocal work requires an Aristotelian analysis of the main theme, or topos, of its text. ${ }^{7}$ In the first step of

3 Wolff, Bach: Essays on His Life and Music, 335; Leaver, 32.

4 Schulze, 15.

5 The use of verbal and musical rhetoric as a feature of Baroque compositional practices is welldocumented. See, for example, George Buelow, "Teaching Seventeenth-Century Concepts of Musical Form and Expression: An Aspect of Baroque Music," College Music Symposium 27 (1987): 3-6; Buelow, "The loci topici and affect in late Baroque Music: Heinichen's Practical Demonstration," The Music Review 27 (1966): 161-62; Buelow, "Rhetoric and Music," The New Grove Dictionary of Music and Musicians (London: Macmillan, 1980), 15:793; Hans Lenneberg, "Johann Mattheson on Affect and Rhetoric in Music," Journal of Music Theory 2 (1958): 47; Donald Boomgaarden, Musical Thought in Britain and Germany During the Early Eighteenth Century (New York: Lang, 1987), 80-81; Claude Palisca, "Ut Oratoria Musica," in The Meaning of Mannerism (Hanover: University Press of New England, 1972), 42, 47; Georgia Cowart, "Critical Language and Musical Thought in the Seventeenth and Eighteenth Centuries," College Music Symposium 27 (1987): 28. For contemporary commentary regarding the importance of verbal and musical rhetoric in composition, see Johann Gottfried Walther, Musikalisches Lexicon (Leipzig, 1732), 34, 41, 172, 177, 178, 227, 228; Charles Avison, An Essay on Musical Expression (London, 1753), 90; J.A. Scheibe, Critischer Musikus (Leipzig, 1745), 682-685.

6 The application of cultural/contextual approaches to early music is strongly advocated by Leo Treitler in "Structural and Critical Analysis" in Musicology in the 1980's, ed. Kern Holoman and Claude Palisca (New York: Da Capo, 1982), 69, and Gary Tomlinson in "The Historian, the Performer, and Authentic meaning in Music," in Authenticity in Early Music, ed. Nicolas Kenyon (Oxford: Oxford University Press, 1990), 120. For documentation supporting the premise that the Crucifixus of the Mass in B minor is a parody of the chorus, "Weinen, Klagen, Sorgen, Zagen," see Marshall, 181; Wolff, Essays, 333; Leaver, 32.

7 From the sixteenth to the late eighteenth centuries, Aristotelian logical and rhetorical principles formed the basis of analytical methodology for both students and scholars in Western Europe. 
such a study, "the Theme [i.e. topos] itself [is] gathered out of the Text" " through the analyst's clarification of "all words of ambiguity or doubt" and subsequent summarization of the overall subject of a work. ${ }^{9}$ Next, the analyst must identify the genus, or general name, under which this topos occurs. ${ }^{10}$ The genus of a topos typically is drawn from one of the ten predicaments, ${ }^{11}$ which collectively represent "those general heads to which all beings and their affections [are]

See W.H. Bruford, Germany in the Eighteenth Century: The Social Background of the Literary Revival (Cambridge: Cambridge University Press, 1965), 232-33, 239-44; Wilbur Samuel Howell, Eighteenth Century British Logic and Rhetoric (Princeton: Princeton University Press, 1971) 14-15, 18; Boomgaarden, 79-81. For contemporary support of this premise, see Thomas Sheridon, A Rhetorical Grammar of the English Language (London, 1781), vii, 157; Thomas Elyot, The boke named the Gouernour (London, 1531), fols. 30v, 35v, 36r; John Newton, An Introduction to the Art of Logik: Composed for the Use of English Schools (London, 1671), fols. A4v-A6; John Locke, Some Thoughts Concerning Education (London, 1693), 223; Jean Pierre de Crousaz, La Logique (London, 1724), 87-91, 220. In addition, Wilbur Samuel Howell's examination of extant eighteenth-century English, French, German, and Italian logic treatises in Eighteenth Century British Logic and Rhetoric, 365, demonstrates that the dissemination and instruction of Aristotelian logic and rhetoric was consistent throughout Europe. Owing to the universality of Aristotelian principles, this study therefore draws freely from sixteenth, seventeenth, and eighteenth-century European sources. There is little doubt that Bach would have been familiar with the methodology outlined in this study, since it in fact reflects the rudimentary principles of Aristotelian logic and rhetoric which were well-known to school children by the age of seven. [Elyot, fol. 30v; Newton, fols. A4v-A5.] Indeed, instruction in Aristotelian and Ciceronian principles formed part of the curriculums of the Lyceum at Ordurf and the Michaelisschule at Lüneburg where Bach had been enrolled as a student. [Eva Mary and Sydney Grew, Bach (New York: Collier, 1962), 25, 30; Philip Spitta, Johann Sebastian Bach: His Work and influence on the Music of Germany 1685-1750, 3 vols. (New York: Dover, 1951) 1: 217; Walther Emery, "Johann Sebastian Bach-Childhood," in The New Grove Bach Family (London: Macmillan, 1983), 45-49.] For more on the close association between Aristotelian and Ciceronian methodology see Lisa Szeker-Madden, “'To Sigh and to be Sad:' An Examination of Sorrow as a topos in the Passionate Ayres of Robert Jones" (M.A. thesis, University of Victoria, 1993), 12.

8 Zachary Coke, Art of Logick (London, 1654), 218. See also de Crousaz, 218; Newton, 25.

9 Newton, 25. See also Coke, 218.

10 Thomas Blundeville, The Art of Logike. Plainly Taught in the English Tongue (London, 1599), fol. B3-B3v; Newton, 25. Thomas Good, in A Brief English Tract of Logick (Oxford, 1677), 4 recognises that a genus contains analogous things which "do differ in special kinds." See also Blundeville, fol. B3; Coke, 20; Newton, 7. Furthermore, Aristotle, in Topics, trans. W.A. Pickard-Cambridge (Toronto: William Benton, 1952), 139b:3, 25-35, 143a: 10, recognises that in order to accurately define a topos, it must be placed within an appropriate genus.

11 de Crousaz, 220; Newton, 7, 24; Aristotle, Topics, 103a: 20-35. In order, the ten predicaments are: substance, quantity, quality, action, passion, relation, time, place, location, and possession. For more on the specific nature of each predicament, see Aristotle, Categories trans. E. M. Edghill (Toronto: William Benton, 1952), lb: 1-25-2a: 1-10; Blundeville, fol. C2v; Coke, 2627; Edward Bentham, An Introduction to Logick (London, 1773), 11-14; Newton, 23-24. 
reduced." ${ }^{12}$ Moreover, John Newton acknowledges that recourse to the predicaments is essential in order to delineate accurately a topos, since "no one and the same numerical thing can be in diverse predicaments." ${ }^{13}$ The identification of the textual elements which ultimately place a topos within a particular predicament occurs in one of two ways. It can result either from the presence of "term words" in a text, which produce a direct statement of these elements, ${ }^{14}$ or it can result indirectly through the author's application of periphrasis (circumlocutio), the latter of which Thomas Wilson defines as a "description either to sette forth a thyng more gorgeouslie, or els to hyde it if the eares cannot beare the open speakyng." 15

Following the identification of the theme of a text and the predicament to which it belongs, the analyst must consider its species, or special name, by uncovering its order within a specific predicament. ${ }^{16}$ Zachary Coke confirms that this is most easily accomplished by considering the "direct degrees" of the topos. ${ }^{17}$ This involves a movement from general to specific in order to establish

12 Bentham, 14. See also Aristotle, Topics, 104a: 1-5; Blundeville, fol. C2v; Joseph Priestley, A Course of Lectures on Oratory and Criticism (London, 1777), 8; Newton, 10; Good, 6; John Eliot, The Logic Primer (Cambridge Mass, 1672), fol. A4v; Antoine Arnauld, Logic: or the Art of Thinking (London, 1685), 65-66. The fact that genus and predicament appear to be synonymous and redundant terms was recognised and commented upon during the eighteenth century. de Crousaz (220-21), for example, criticises one author's definition of colour for these very redundancies, since the author names the genus of colours as the predicament of quality. John Locke (223) also criticizes the use of genus and predicaments as the basis of logic, professing that "Right Reasoning is founded on something other than the predicables [i.e.genus and species] and the predicaments." Similar criticisms can be found in the writings of the German logician, Christoph Wolff, as well as in those of the Port Royalists. [See Howell, 24, 364-71.] This controversy, however, had little effect on education, and Aristotelian logic remained the dominant system in Europe during the seventeenth and eighteenth centuries. [Howell, 13-15; Bruford, 239-41.]

13 Newton, 28. See also Coke, 19.

14 Coke, 15.

15 Thomas Wilson, The Arte of Rhetorique (London, 1553), 351. Interestingly, periphrasis represents both a textual rhetorical figure and a conventional method of definition. [George Puttenham, The Arte of English Poesie (London, 1589), 161; Richard Sherry, A Treatise of Schemes and Tropes (London, 1550), 44; Henry Peacham the Elder, The Garden of Eloquence, (London, 1577), 48, 123] For more on other conventional methods of definition see Aristotle, Posterior Analytics, trans. G.R.G. Mure (Toronto: William Benton, 1952), 93b-94a, 97a-98a; Blundeville, fols. G4-G4v; Newton, 5.

16 Newton, 25;Coke, 214;Good, 4; de Crousaz, 87; Bentham, 16. Blundeville [fol. B3] acknowledges that a species contains "manie thinges differing only in number." See also Newton, 8; Good, 4.

17 Coke, 20. 
the "certain circumstances of existence" that are unique to the topos. ${ }^{18}$ According to John Newton, this stage of analysis is essential in order to determine "what a thing is." 19 For two topoi to be considered identical, therefore, they must not only possess analogous themes, but they must also belong to the same predicament and share the same species.

Once the topos of a text has been established by revealing its theme, genus/ predicament, and species the analyst must "let the Amplifications be diligently severed from the Explication of the theme." 20 These "amplifications," or ornaments, consist chiefly of tropes and rhetorical figures, which aid in "the forceable moving of the affections, [and] doth after a sort beautifie the sense and the very meaning of a sentence." ${ }^{21}$ In fact, it is because of their ability to enhance the comprehension of a text that George Puttenham declares rhetorical figures essential to both poetry and oration:

our writing and speeches publike ought to be fig-uratiue, and if they be not doe greatly disgrace the cause and purpose of the speaker $\&$ writer. $^{22}$

These figures are equally effective in music. Indeed, J.A. Scheibe declares:

The use of figures is certainly of the same nature in music as in oratory and poetry... . Since music, particularly, is concerned with the arousal and expression of the passions; since it must move and agitate the hearts of men; since, after all, it should captivate and fascinate the listener with its fire; can it really use any other means than those which are found in poetry and oratory? ${ }^{23}$

18 Coke, 20, 24. There is another method of identifying the species of a topos. This is through the recognition of its "collateral degrees." Collateral degrees delimit a topos through the application of "difference," an operation which does not "show what a thing is, but of what manner it is." As an example, Coke employs "difference" in order to define humanity. He asks, for instance, "What manner of living creature is man?" and recognises that man is "a reasonable, living creature." Man's ability to reason, therefore, represents the "difference" which separates him from all other living creatures (Coke, 20, 24, 25-26).

19 Newton, 8.

20 Coke, 219.

21 Dudley Fenner, The Artes of Logike and Rhetorike, translated out of the Rhetoric Treatise by Omer Talon (Middleburg, 1584), 171.

22 Puttenham, 115.

23 "Da nun aber die Musik insonderheit mit Erregung und mit dem Ausdrucke der Gemüthsbewegungen zu thun hat; da sie die Herzen der Menschen rühren and bewegen muB; da sie endlich die Zuhörer durch ihr Feuer einnehmen und gleichsam bezaubern soll: kann sie 
The application of an Aristotelian analytical approach to the opening chorus of Cantata 12 and to its parody, the Crucifixus of the Mass in B minor (BWV 232), reveals that a consideration of their topoi overshadows all other criteria in Bach's selection of an appropriate model for the parody version, since both texts possess similar themes, belong to the same predicament and share the same species.

Examination of the text for the opening chorus of "Weinen, Klagen, Sorgen, Zagen" confirms that its basic theme focuses on the suffering which Christians must endure because of humanity's sins. The topos of this text, therefore, belongs to the predicament of passion, which involves the receiving of an action. ${ }^{24}$ Zachary Coke states that this predicament is defined from the perspective of the "patient," the receiver of the action, rather than from the perspective of the "agent," the instigator of the action. ${ }^{25}$ In the text of this chorus, term words identify the patient as "Christians" through a direct statement of this word at line 4. In contrast, periphrasis defines the passion inflicted upon Christians as suffering, owing to the images of torment presented in the first three lines. Periphrasis also is used to describe the agent of the passion as sin, through the phrase, "who bear the mark of Christ" (line 5). This phrase suggests that Christians follow Christ's example. Consequently, since sin motivated the suffering and death of Christ, it likewise motivates the suffering of Christians. ${ }^{26}$

wohl hierzu andere Mittel ergreifen, als diejenigen, welche der Dichtkunst und der Redekunst gemein sind?" [Scheibe, 683.] All translations are those of the author, unless otherwise specified. The link between musical and textual figures also is discussed by Johann Mattheson, in Der Vollkommene Capellmeister (Hamburg, 1739) trans. Hans Lenneberg in Notes 30 (1958): 202, who recognises that the word figures and phrase figures of textual rhetoric are directly transferable to music. See also Henry Peacham the Younger,The Compleat Gentleman (London, 1622), 98, 103.

24 Coke, 42; Blundeville, fol. F3. For the purposes of this study, additional applications to the word "passion" refer to its meaning as a predicament rather than to its meaning as a strong emotion. In general, the passions of the mind (i.e. strong emotions) belong to the predicament of quality. More specifically, their species involves the third kind of quality, namely, passions and passible qualities. For more on the order of the passions of the mind in the predicamental series, see Szeker-Madden, 13-15; Aristotle, Categories, 9a: 25-35; Blundeville, fol. E3-E3v; Coke, 3238; Bentham, 12; Newton, 30; Good, 9.

25 Coke, 42. See also Newton, 33.

26 The belief that Christ died for our sins represents one of the main tenets of the Nicene creed, the intonation of which was a regular part of the Lutheran service during Bach's time (Stiller, 122123; Jaroslav Pelikan, Bach Among the Theologians [Philadelphia: Fortress Press, 1986], 126). Interestingly, Bach chose this version of the creed for the credo section of his Mass in B minor (Pelikan, 123). 
Bach, "Weinen, Klagen, Sorgen, Zagen," BWV 12/1.

Weinen, Klagen,

Sorgen, Zagen,

Angst und Noth

Sind der Christen Thränenbrod

die das Zeichen tragen
Weeping, lamenting,

Worrying, quaking,

Anxiety and distress:

[These] are the bread of affliction for Christians

Who bear the mark of Christ.

Consideration of the direct degrees of this topos reveals a species of three circumstances. First, the topos is inferior, since it occurs on earth. ${ }^{27}$ Second, it is special, because it involves man. ${ }^{28}$ Third, it is defective, owing to the fact that it results from evil and immorality. ${ }^{29}$

Application of the same techniques to the text of the Crucifixus movement from Bach's Mass in B minor, BWV 232 demonstrates an equivalency of topos between this text and that of the cantata chorus, "Weinen, Klagen, Sorgen, Zagen." Indeed, the basic theme of the Crucifixus is identical to that of the cantata movement, since it also concerns the suffering inflicted upon a man, Christ, because of humanity's sins. As a result, the topos of this text belongs to the predicament of passion. Periphrasis indirectly defines the patient of this passion as Christ through the archetypal images of crucifixion (line 1), Pontius Pilate (line 2) and suffering (line 2). In like manner, periphrasis identifies the agent of the passion, since the phrase "on our behalf" (line 1) suggests "our sins" as the motivation for Christ's crucifixion and suffering. While indirect statement through periphrasis defines both the patient and the agent of the passion, the passion itself is defined through term words. Specifically, the use of the word "passus" at line 2 provides a direct statement of the passion as suffering.

Bach, Mass in B minor, BWV 232/17.

Crucifixus etiam pro nobis $\mathrm{He}$ was crucified also for us

sub Pontio Pilato passus

et sepultus est

suffered under Pontius Pilate

and was buried

Direct degrees demonstrate that the topos of this text possesses a species of the same three circumstances as that of the opening chorus of Cantata 12. Indeed, the first circumstance of this topos is inferior, since the passion takes place on 


\begin{tabular}{|l|l|l|}
\hline \multicolumn{2}{|c|}{ Determination of the Predicament } \\
\hline & BWV $12 / 1$ & BWV 232/17 \\
\hline PATIENT & Christians & Christ \\
\hline AGENT & sin & sin \\
\hline PASSION & suffering & suffering \\
\hline
\end{tabular}

Determination of the Species

\begin{tabular}{|l|l|l|}
\hline & BWV 12/1 & BWV 232/17 \\
\hline INFERIOR & occurs on earth & occurs on earth \\
\hline SPECIAL & involves men & involves Christ as a man \\
\hline DEFECTIVE & $\begin{array}{l}\text { caused by the evil and } \\
\text { immortality of sin }\end{array}$ & $\begin{array}{l}\text { caused by the evil and } \\
\text { immporality of sin }\end{array}$ \\
\hline
\end{tabular}

Example 1: Comparison of the topos for the texts of BWV 12/1 and BWV 232/17.

earth. The second is special, because the passion is inflicted upon Christ as man. The third is defective, in view of the fact that the immorality and evil associated with sin produce the passion. Thus, as the charts in example 1 demonstrate, the topos of the Cantata movement and the Crucifixus movement are identical, since they share the same predicament and species.

While use of the first three stages of an Aristotelian analytical approach reveals that the texts of both versions possess equivalent topoi, application of the fourth stage of this technique demonstrates an additional similarity between the model and the parody, since identical textual and musical-rhetorical figures effectively enhance the elements which define the topos at corresponding points in both versions.

The first of such occurrences involves the descending chromatic ground bass on which both the model and its parody are built. In fact, the parody differs from the model only through an increase in rhythmic activity and through a transposition from the original key of $\mathrm{F}$ minor to $\mathrm{E}$ minor. Chromatic movement of this type produces the musical-rhetorical figure, pathopoeia. ${ }^{30}$ According to Charles Avison, "such Chromatic Strains ... are mimetic of grief and anguish." ${ }^{11}$ This figure consequently reinforces the topos of both the parody and the model by

30 Sébastien de Brossard, Dictionaire de Musique (Paris, 1703), "Fugue Pathétique," fol. e2v and "Pathétique," fol. u2v; Avison, 62-63; James Grassineau, A Musical Dictionary (London: J. Wilcox, 1740), 176.

31 Avison, 63. 
aurally establishing suffering as the passion inflicted upon the patient of each text.

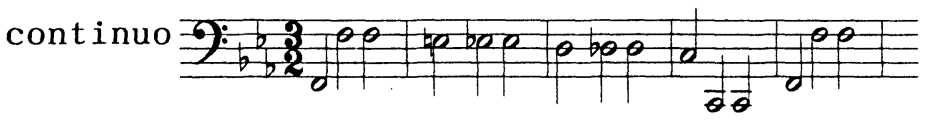

Example 2: Bach, "Weinen, klagen, sorgen, zagen," BWV 12/1, mm. 1-5.

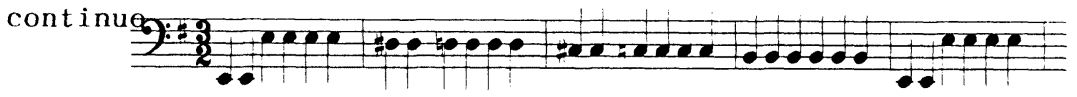

Example 3: Bach, Mass in B minor, BWV 232/17, mm. 1-5.

Coupled with the figure pathopoeia in the choral movement, "Weinen, Klagen, Sorgen, Zagen," are two additional rhetorical figures, namely, polyptoton and epizeuxis. In his musical dictionary, James Grassineau acknowledges that polyptoton occurs when

after a little silence one part repeats or runs over the same notes, the same intervals, the same motions, and in a word, the same song which a first part had already gone over during the silence of this. ${ }^{32}$

This figure takes place at mm. 1-9 of the model, where the material of the chorus at mm. 1-5 is restated with a different succession of voices at mm. 5-9. The second figure of my list, epizeuxis, involves the immediate repetition of a word or phrase. ${ }^{33}$ It is evident at mm. 1-9 of the same movement, since the text at $\mathrm{mm}$. 5-9 represents a direct restatement of the text at $\mathrm{mm}$. 1-5.

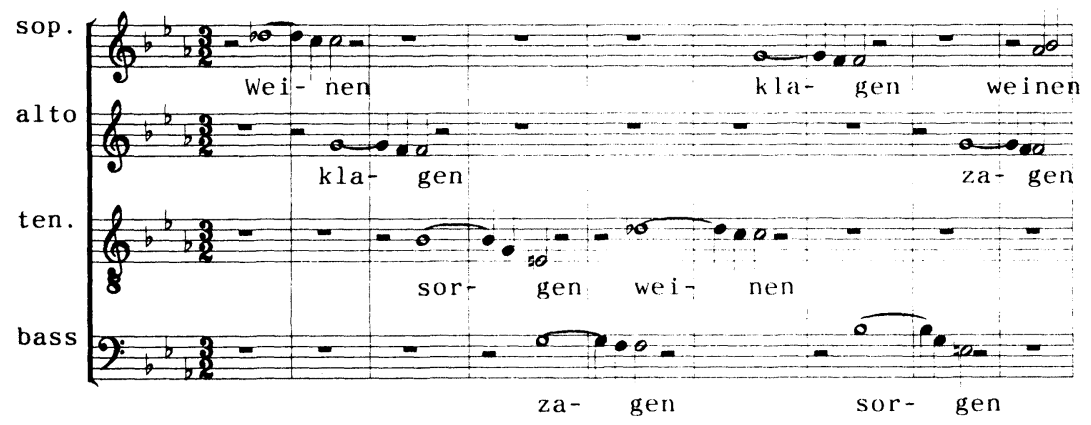

Example 4: Bach, BWV 12/1, mm. 1-9, vocal parts only.

32 Grassineau, 197. See also Scheibe, 690; Brossard, fol. il.

33 Puttenham, 167; Peacham the Elder, 59; John Hoskyns, Directions for Speech and Style (London, ca. 1599), 125; John Smith, The Mysterie of Rhetorique Unvailed (London, 1657), 89-90; Abraham Fraunce, The Arcadian Rhetorike, (London, 1588), fol. C5v; Wilson, 398. 
Both polyptoton and epizeuxis are employed in a similar manner in the parody version. Polyptoton, for example, takes place at mm. 5-13 of this movement, since the material at $\mathrm{mm}$. 5-9 recurs in a different order at $\mathrm{mm}$. 9-13. Interestingly, aside from a change of rhythm in order to accommodate text underlay, the composition of polyptoton in these measures of the Crucifixus is identical to its composition at mm. 1-9 of "Weinen, Klagen, Sorgen, Zagen." Epizeuxis also arises in the same manner as in the original version, since the text at $\mathrm{mm}$. 9-13 provides an immediate repetition of the text which preceded it at mm. 5-9.
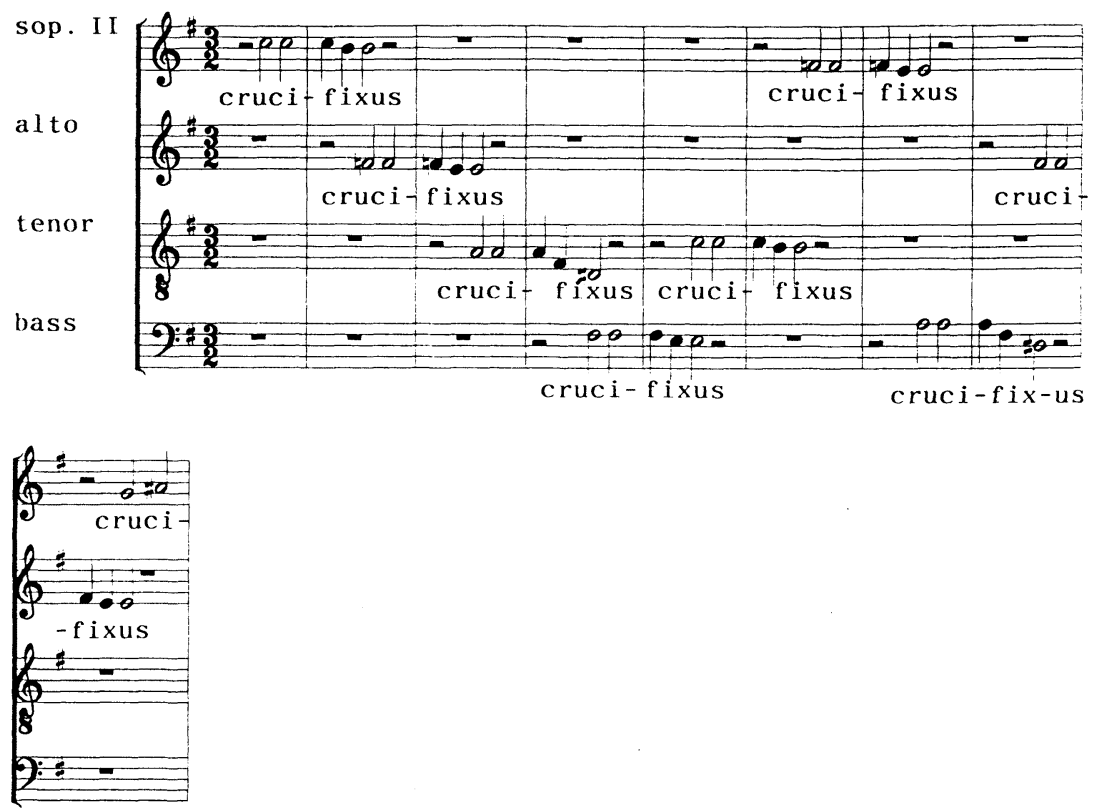

Example 5: Bach, 232/17, mm. 5-13, vocal parts only.

The figures employed in these passages each possess the ability to enhance elements which define a topos. Scheibe acknowledges that polyptoton, for instance, allows "the comprehension of a piece or the understanding of the discourse itself [to] receive greater emphasis." 34 In like manner, epizeuxis strengthens the ideas of a text, because, as Thomas Wilson observes, the repetition which this figure provides "doth stir the minde of the hearer." ${ }^{35}$ In the 34 “... der ganze Zusammenhang des Stückes, oder auch der Verstand der Rede selbst einen großen Nachdruct bekömmt” (Scheibe, 689-90).

35 Wilson, 398. 
model, the combination of these figures reinforces the definition of the topos by emphasizing the indirect statements which establish the passion as suffering. Similarly, in the parody, polyptoton and epizeuxis enhance the topos of this text by accentuating an occurrence of periphrasis which identifies the patient of the passion as Christ.

An additional rhetorical correspondence between the opening chorus of Cantata 12 and the Crucifixus of the Mass in B minor takes place at mm. 16-18 of the model and at mm. 20-22 of the parody. The figure evident in these measures is anaphora, which occurs when "we imitate only the movement or the shape of the notes." 36 In both versions, anaphora involves the alto and soprano voices, respectively. Indeed, the movement of the first four notes of the alto voice in each example is repeated up a tritone in the soprano voice. A further figure, epizeuxis, accompanies the musical repetitions of anaphora in both versions. In the model, this figure results from the immediate reiteration of the word "weinen," and in the parody it takes place through the direct restatement of the word, "etiam."

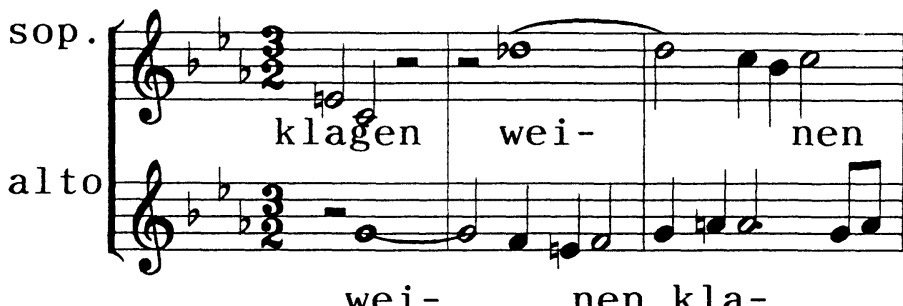

Example 6: Bach, BWV 12/1, mm. 16-18, soprano and alto parts only.

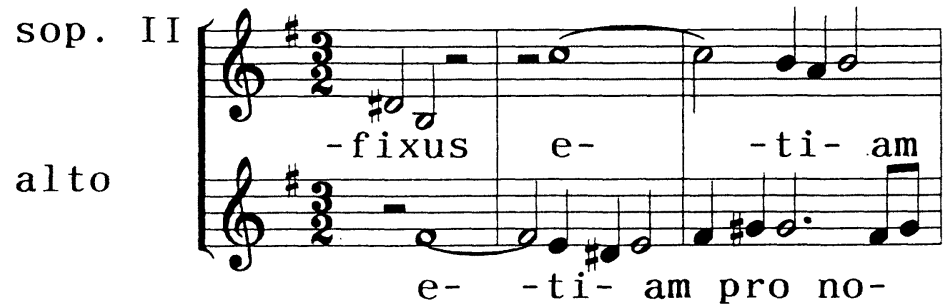

Example 7: Bach, BWV 232/17, mm. 20-22, soprano and alto parts only.

36 “... on imite seulment le mouvement, ou la figure des Nottes” (Brossard, fol. i1). See also Mattheson, Der Vollkommene Capellmeister, 203; Walther, 34. 
The addition of anaphora and epizeuxis to both the model and its parody intensifies the definition of the topos in each respective text. Indeed, the rhetorical artifice at mm. 16-18 of the model enhances the setting of the word, "weinen" and correspondingly strengthens an example of periphrasis which illustrates the passion as suffering. Similarly, the figures at mm. 20-22 of the parody amplify the word "etiam," which itself represents a further textual figure, namely: epitheton. According to George Puttenham, this figure occurs when "ye will speake giving every person or thing a quality by way of addition." ${ }^{37}$ In this case, the figure results from the use of the adverb, "etiam" to modify the phrase, "pro nobis." The application of anaphora and epizeuxis therefore heightens the effectiveness of epitheton which in turn enhances the phrase, "pro nobis," an indirect statement that identifies the agent of the passion as sin.

Yet another rhetorical parallel between "Weinen, Klagen, Sorgen, Zagen" and the Crucifixus of the Mass in B minor involves mm. 20-22 of the original, which correspond with $\mathrm{mm}$. 24-26 of the parody. The musical figure observed in these measures is gradatio, which Johann Mattheson defines as "the stepwise design of all that is written, sung or played." 38 In both versions, this figure takes place in the tenor voice. Specifically, the motif at mm. 20-21 of the model, e'flat-d'-c', is repeated down a step at mm. 21-22. Likewise, in the parody version, the motif at mm. 24-25, d'-c'-sharp-b, recurs down a step at mm. 25-26.

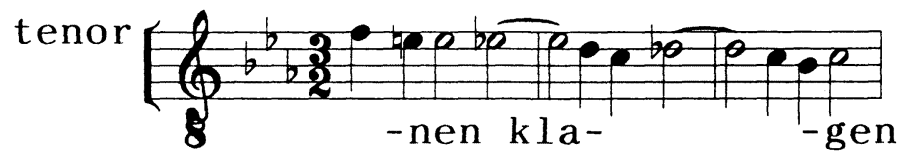

Example 8: Bach, BWV 12/1, mm. 20-22, tenor part only.

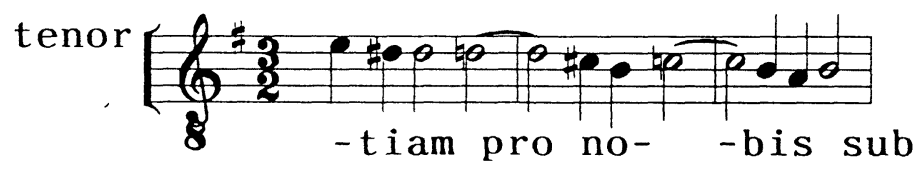

Example 9: Bach, BWV 232/17, mm. 24-26, tenor part only.

37 Puttenham, 147; Peacham the Elder, 47.

38 Mattheson, 206. See also Charles Butler, The Principles of Musik (London, 1636), 51; Walther, 172; Scheibe, 697. 
According to Scheibe, gradatio "always proves that the composer has understood the power of the high art of composition... [and] moves the attentive listener to astonishment." 39 In "Weinen, Klagen, Sorgen, Zagen," this figure serves to draw the auditor's attention to the word "klagen." It consequently aids in the determination of the predicament to which the topos belongs by reinforcing an appearance of periphrasis that identifies the passion as suffering. Similarly, in the parody version, gradatio enhances the definition of the topos by intensifying the statement of the phrase "pro nobis," a phrase which characterises the agent of the passion as sin.

Equally important is the rhetorical link between the model and the parody that is established by a further appearance of the figure, pathopoeia. In both versions, this figure occurs in the soprano voice, which chromatically descends a minor third, moving from g'-e' at mm. 22-25 of the model and from f'-sharpd'-sharp at mm. 26-29 of the parody. In comparison with its initial appearance at the opening of both versions, this second application of pathopoeia also serves to enhance the definition of the topos. In the model, for instance, it coincides with the word, "zagen," a word which identifies the passion as suffering through periphrasis. It is employed in a similar fashion in the parody, where it accompanies the noun, "Pontio Pilato," and thus reinforces an occurrence of periphrasis which establishes the patient of the passion as Christ.

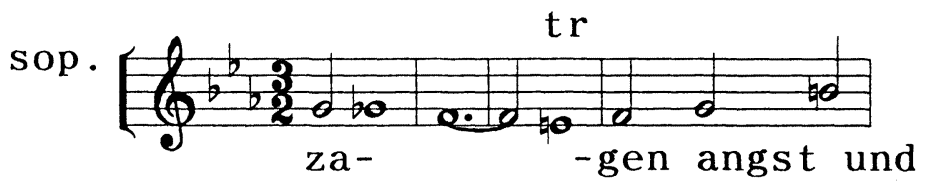

Example 10: Bach, BWV 12/1, mm. 22-25, soprano part only.

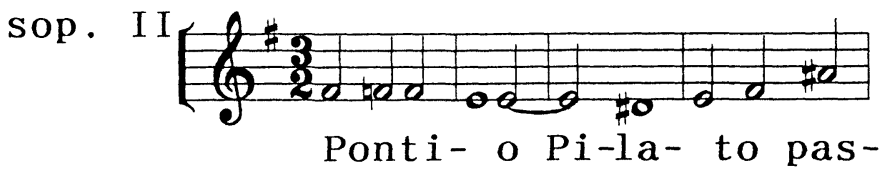

Example 11: Bach, BWV 232/17, mm. 26-29, soprano part only.

The combination of two further musical-rhetorical figures, noema and gradatio, immediately follows this latter example of pathopoeia in both versions. Johann Walther defines noema as "a thing wherein consonant homophony suddenly is heard and put forward." ${ }^{\prime 0}$ This figure occurs at mm. 25-28 of the

39 “... sie allemal beweist, daß der Componist die Stärke der hohen Schreibart zu erreichen gewußt hat" (Scheibe, 697). 
model and at mm. 29-32 of the parody, respectively, where each voice of the chorus abruptly combines to produce note-against-note harmony. Gradatio regulates the overall melodic movement of this section. In fact, following the cadential resolution on the first beat at $\mathrm{m}$. 25 of the model and on the first beat at $\mathrm{m} .29$ of the parody, each voice sings a motif of three beats which is repeated in descending step-wise motion. Aside from the musical-rhetorical figures in these passages, a textual rhetorical figure, epizeuxis, also is evident. This figure results from the immediate restatement of the phrase "Angst und Noth" in each voice of the model, and the repetition of the word "passus" in the tenor voice of the parody.

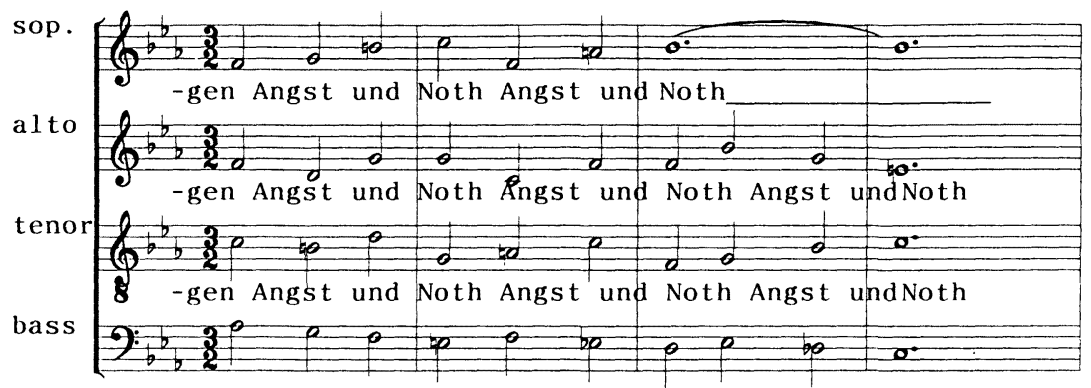

-gen Angst und Noth Angst und Noth Angst und Noth

Example 12: Bach, BWV 12/1, mm. 25-26, vocal parts only.

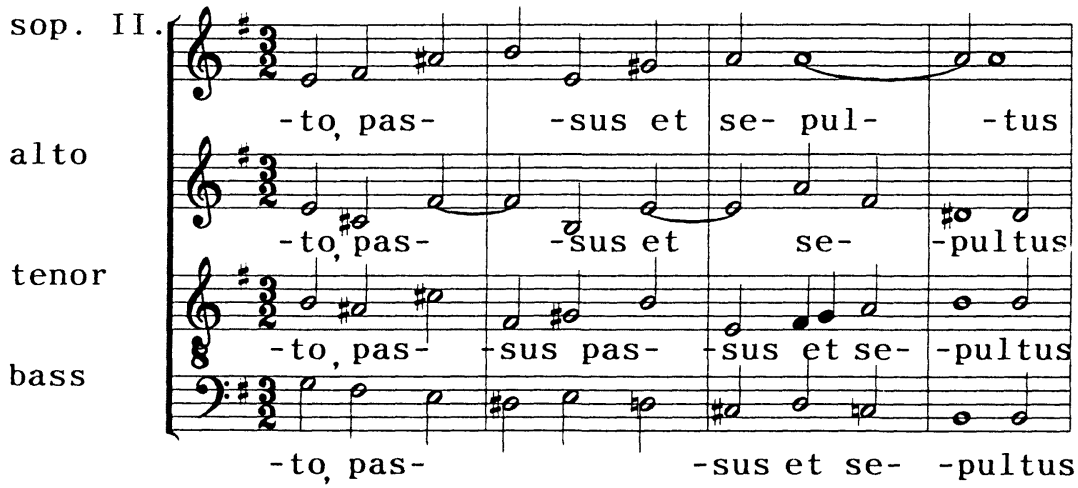

Example 13: Bach, BMV 232/17, mm. 29-32, vocal parts only.

40 "ein solcher Sass, worinn lauter Consonanzen auf einmal gehört und hervor werden."

[Walther, 443-44.] 
In comparison with the previous examples of rhetorical artifice, the musical and verbal figures of these measures are equally compelling in their enhancement of the topos. In the model, for instance, they effectively emphasise the declaration of the passion as suffering by stressing the indirect statement of this concept which occurs in the line "Angst und Noth." These figures provide similar intensification of the topos of the parody version, where they combine to strengthen the iteration of phrase "passus et sepultus," a phrase which employs periphrasis to both reveal the patient of the passion as Christ and identify the passion as suffering.

Additional accentuation of the topos results from the rhetorical artifice found at mm. 33-37 of the model and at mm. 37-41 of the parody. Two figures occur in these passages: first, the musical figure, anaphora and second, the textual figure, epizeuxis. In the model, anaphora involves the repetition of the soprano voice material at $\mathrm{mm}$. 33-34 down a perfect fifth in the alto voice at $\mathrm{mm}$. 34-35. This figure also results from the restatement of the three-note motif in the tenor voice at $\mathrm{mm}$. 35-36 down a perfect fifth in the bass voice at $\mathrm{mm}$. 3637. Besides anaphora, epizeuxis also takes place in these same measures of the model. The triple reiteration of the line "Angst und Noth" in the soprano voice produces one example of this figure. A further example of epizeluxis in these measures results from the successive vocal entries, which collectively produce a quadruple restatement of the line "Angst und Noth."

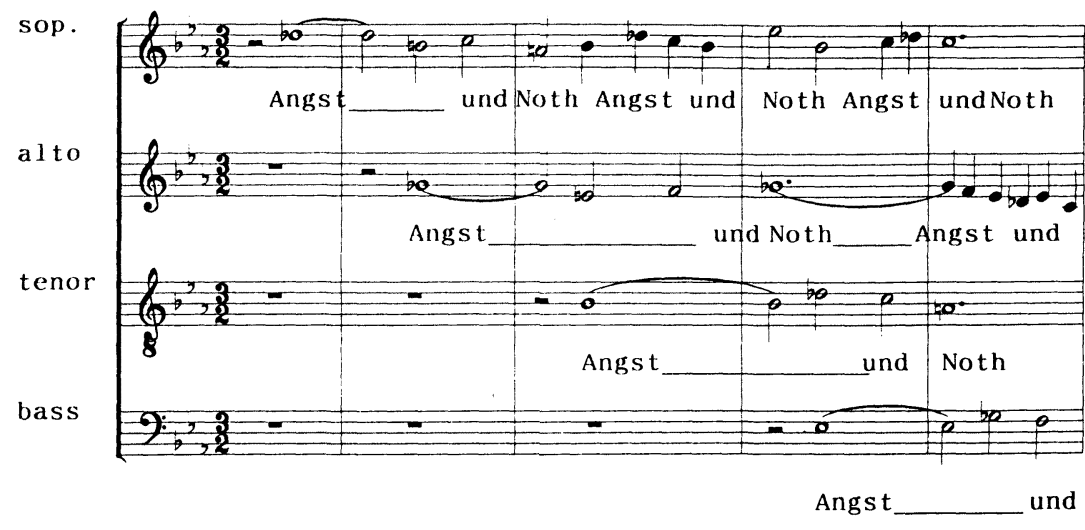

Example 14: Bach, BWV 12/1, mm. 33-37, vocal parts only. 
The distribution of the material which creates the figure anaphora in the model is identical in the parody version. Indeed, the material of the alto voice at mm. 38-39 represents a transposition of the soprano material at $\mathrm{mm}$. 37-38. Likewise, the bass motif at $\mathrm{mm}$. $40-41$ is a repetition a fifth lower of the tenor motif at mm. 39-41. The application of the figure epizeuxis in the parody, however, is modified. That is, while the successive vocal entries maintain the quadruple repetition of text, the soprano voice lacks the triple textual reiteration which occurs in the model.

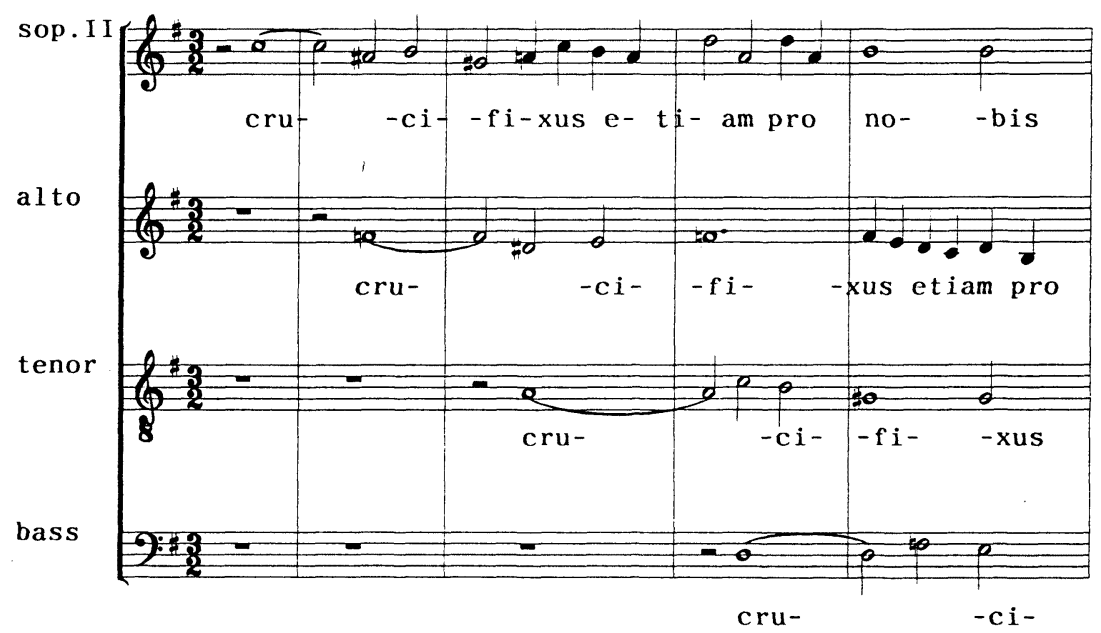

Example 15: Bach, BWV 232/17, mm. 37-41, vocal parts only.

The use of these figures in both the model and the parody is deliberate, since, in each case, anaphora and epizeuxis reinforce the definition of the topos. In the model, for instance, they intensify an occurrence of periphrasis which identifies the passion as suffering. Likewise, in the parody version, these figures reinforce the presentation of material which identifies the patient as Christ.

The application of Aristotelian analytical techniques to Bach's cantata movement, "Weinen, Klagen, Sorgen, Zagen," BWV 12/1, and to its parody, the Crucifixus of the Mass in B minor, BWV 232/17, therefore confirms that Bach's choice of an appropriate model from which to borrow involved more than a cursory consideration of musical or textual elements. Indeed, by probing deep into the rhetorical structure of both the cantata movement and the Crucifixus, the first three stages of this analysis reveals that an equivalence of topoi between the text of the original and that of the parody represented an important criterion for the selection of a model. Moreover, the fourth stage of 
this analysis demonstrates that parallel textual and musical rhetorical figures intensify elements which define the topos of both versions. In the model, for instance, the various figures serve to amplify a single topos-defining aspect, namely, the presentation of ideas which identify the passion as suffering, while in the parody, rhetorical artifice emphasizes all elements of the topos..$^{41}$ Bach's application of the parody procedure thus represents his deliberate reuse of rhetorical figures that are appropriate for the embellishment of works with identical topoi. As a result of this type of contextual study, we can remove the speculation which has created the parody problem in Bach's music, and, more importantly, we can "avoid the philosophical mistake of arranging in the past what is actually present experience." 42

\begin{abstract}
Even though parody and borrowing have long been recognized as legitimate features of Bach's compositional practices, the criteria by which the composer selected appropriate material to parody remains problematic. Christoph Wolff and Güther Stiller, for example, suggest that musical elements, such as the quality of the original or its potential for further embellishment, represent possible criteria. On the other hand, textual elements such as analogous subjects, "affects," and metrical patterns between old and new texts also many have factored into Bach's criteria. In an effort to redress the imposition of these twentiethcentury solutions to what is in effect an eighteenth-century phenomenon, this study
\end{abstract}

41 Consideration of the verbal rhetorical artifice inherent in the text of the model explains the apparent disparity of rhetorical emphasis between Bach's setting of BWV 12/1 and BWV 232/ 17. Indeed, the first three lines of BWV $12 / 1$ combine to produce the textual-rhetorical figure synathroismus, which Peacham the Elder, 113, defines as "a multiplication or heaping togeather of many wordes, signifynge dyuers things of like nature." In this case, different examples of suffering are "heaped" together in order to emphasise the passion that is inflicted upon the patients. The remaining lines provide two examples of a different figure, namely, methaphor. In fact, the word "Thränenbrod" at 1.4 and the phrase "die das Zeichen tragen" at 1.5 are both metaphorical references to Christian suffering. Metaphor and synathroismus, however, provide different levels of rhetorical intensification. The figure metaphor, for instance, is a part of the middle category of rhetorical figures, that is, the sensable figures, which appeal to the mind of the auditor and are confined to poetry. In contrast, synathroismus is contained in the highest level of rhetorical figures, the sententious figures, which appeal to the mind and the ear of the auditor and belong to the realm of oratory. Bach therefore chose to couple his addition of rhetorical artifice in BWV $12 / 1$ with those elements that make up the more emphatic figure. For more on Puttenham's classification of the different levels of rhetorical intensification, its relation to other contemporary sources, and the level of rhetorical intensification provided by specific textual figures, see Szeker-Madden, 120-31.

42 Tomlinson, 120. 
undertakes a cultural/contextual examination of the Crucifixus movement from the Mass in B minor and its model, the opening chorus of Cantata 12. Indeed, a logical analysis of both texts reveals that an equivalence of topoi, or topics, reporesents an important criterion in the selection of an appropriate model from which to borrow. Moreover, a musical-rhetorical analysis confirms that Bach's borrowings from the opening chorus of Cantata 12 are actually musical-rhetorical figures. His application of the parody procedure thus represents the re-use of specific musical-rhetorical gestures which are suitable for the embellishment of a particular topos.

[All references to the text and music of BWV 12/1 are from the Neue Bach Ausgabe, ed. Reinmar Emans (Kassel: Bärenreiter, 1982), ser. 1, 11: 7-11. All references to the text and music of BWV 232/17 are from the Neue Bach Ausgabe, ed. Friedrich Smend (Kassel: Bärenreiter, 1954), ser. 2, 1:160-63. Musical examples are reprinted by permission.] 